\title{
PPP2CB wt Allele
}

National Cancer Institute

\section{Source}

National Cancer Institute. PPP2CB wt Allele. NCI Thesaurus. Code C49435.

Human PPP2CB wild-type allele is located within 8p12 and is approximately $27 \mathrm{~kb}$ in length. This allele, which encodes serine/threonine-protein phosphatase 2A catalytic subunit beta isoform protein, is involved in the dephosphorylation of phosphoproteins. 